\title{
Groundwater Depletion and Role of Direct Seeded Rice in Water Saving: A Move Towards Sustainable Agriculture of Punjab
}

\author{
Sumit Bhardwaj" and Baljinder Kaur Sidana
}

Department of Economics and Sociology, Punjab Agricultural University, Ludhiana-141004, Punjab, India

*Corresponding author: sumitbhardwaj@pau.edu

\begin{abstract}
Presently, out of 20 million tube wells in the country, almost 1.3 million are in Punjab, contributing to fastpaced groundwater extraction and its depletion. Direct seeding of rice has a great potential for optimizing the water-use efficiency in paddy cultivation without any disturbing and harmful effect on its productivity, if weeds are controlled properly. A significant saving of 18 per cent was achieved for irrigating one hectare of the DSR farm in basmati and non-basmati varieties as compared to non-DSR farm. The mean overall technical efficiency was more in DSR farms as compared with non-DSR farms, with difference of about 12 per cent in basmati and 5 per cent in non-basmati fields. However, this difference was 7 per cent in basmati and 14 per cent in non basmati while calculating the average technical efficiency w. $r$. $t$ wateruse. Popularization of this technology among farmers in a participatory mode on a comprehensive scale needs a focused attention through capacity building of farmers.
\end{abstract}

Keywords: Direct Seeding Rice, Data Envelopment Analysis, Efficiency, Groundwater

A transformation represented by an on-going shift from conventional to conservation agriculture i.e., from an earlier set of principles based on massive soil inversion with a plough towards a new set of principles based on minimal soil disturbance, management of crop residues and innovative cropping system is best option of farming under rice-wheat cropping system. Recent studies indicate a slowdown in the productivity of growth in the rice-wheat systems of India (Kumar et al. 2002). Evidence from long-term experiments shows that crop yields are stagnating and sometimes declining (Duxbury et al., 2000; Ladha et al. 2003). Current crop cultivation practices in rice-wheat system degrade the soil and water resources thereby threatening the sustainability of the system (Ali and Byerlee 2000; Duxbury et al. 2000; Gupta et al. 2003; Kumar and Yadav 2001; Ladha et al. 2003). As a result, food security in the country remains a challenge for the future. If the supply of food is to keep pace with the rapidly growing demand, rice-wheat farmers will have to produce more food from fewer resources while sustaining the environmental quality. In this regard, direct seeded rice is a good alternative of transplanting and yield potential of direct seeded rice is equivalent to the transplanted rice under good water management and weed conditions (Awan et al. 1989; Mitchell et al. 2004). Direct seeded rice yields higher than traditional transplanted rice by $3-17$ per cent and required 19 per cent less water with increased water productivity by $25-48$ per cent (Tabbal et al. 2002).

Direct seeding of rice (DSR) is a method of growing rice under aerobic conditions where seeds are sown directly in the field with the help of seed drill and water is not kept standing in the field. The crop is irrigated at relatively lesser frequency. At global level, 23 per cent rice is direct seeded. In Asia, rice is sown directly on an area of about 29 million hectare where as in India this area is $42 \mathrm{~m}$ ha (Pandey and Velasco, 2002; Patil et al., 2005). However in Punjab, rice is cultivated through nursery /transplanting of 
seedlings with flood irrigation method, wherein water usage is high and water-use efficiency is low.

Moreover, agriculture in Punjab has reached a stage where further additions to production are best with increasing cost, making it a high cost sector. There is no possibility of increasing area under cultivation; the increase in output mainly depends upon on the development and adoption of an agricultural technology that can relax the constraints on growth imposed by inelastic supply of land. There is increasing evidence of stagnation in crop yield potential, and some indications that average yields of major crops in state have platitude. The continuous degradation of natural resources notably underground water and soils results in sharp decline in net farm profitability and increased cost of cultivation (Sidhu et al. 2010). As per the Central Groundwater Board (CGWB) estimates, total annual draft of groundwater in Punjab is 72 per cent higher than the net annual replenishable level of 20 Billion Cubic Metre (BCM) (Srivastava et al. 2015). There has been sharp rise in the total number of tubewells from 1.92 lakh in 1970-71 to 10.73 lakh in 2000- 01 and further to 14.05 lakh in 2013-14 in the state. The diesel operated tubewells showed an increase till the year 2005-06, thereafter showing a decline and the number has declined to 1.79 lakh in 2013-14. The number of electric operated tubewells is continuously rising from 0.91 lakh in 1970-71 to 7.88 lakh in 2000-01 and further to 12.26 lakh in 2013-14. Subsidized power to agriculture led to installation of more and more electric tubewells and consequent greater withdrawal of ground water than ever before. The density of tubewells per thousand hectare of Net Sown Area (NSA) for the state was 66 in 1980-81, which rose to 287 in 201213 . This clearly explains the extent of ground water exploitation in Punjab (Kaur et al. 2015).

The study of input use efficiency acquires a special importance to determine whether there exists an unexploited potential for increasing farm incomes by optimizing use of various farm inputs. Productivity differences across farms, which produce a single output with multiple inputs occur because some of them cannot use available technology efficiently (not producing maximum output with given input) because of failures to combine inputs in correct proportions at given factor prices (allocative efficiency) or because of uncontrolled factors such as variation in land situation, natural, biological and human factors such as soil type, erratic rainfall, flood, drought, outbreak of pest and diseases (Kalirajan, 1985). Further, for the purpose of national policy and planning, the comparison of resource use pattern and production efficiency among various farm categories provides an economic guideline to allocate the resources in proportions which help the economy to exploit its production potential to the maxima. In this regard, direct seeded rice (DSR) has an edge over transplanted rice, without any adverse impact on productivity, if weeds are controlled properly. Keeping the above facts in view, the present paper highlights the increase in productivity as well as water use efficiency of DSR over puddled/transplanted (non-DSR) rice.

\section{Data base and Methodology}

The primary data for the year 2012-13 was collected using multi-stage purposive sampling technique. As direct seeding of rice technology is being practiced in certain pockets of Punjab, two districts viz. Faridkot and Ferozepur were purposively selected. Further, two blocks from each of selected district and then cluster of villages from these blocks were selected based on the concentration of farmers using DSR technology. In order to undertake impact assessment task of this technology, almost an equal number of non-adopters from the same vicinity were also taken as a control group in the analysis. Therefore, a total sample of 80 farmers (40 adopters and 40 non-adopters) covering six villages, two blocks and two districts of Punjab state was finally chosen for the present study.

The selected sample farmers had grown either nonbasmati varieties (PR-114,PR-118) or basmati variety (Pusa Basmati 1121), whereas DSR practising sample farmers in selected districts had mostly grown basmati variety (Pusa Basmati 1121). Basmati as reported by sample farmers is less susceptible to insect/pest attack and is more resistant to weeds when using DSR technology as compared to other paddy varieties. Owing to differences in sowing/ harvesting periods, time of maturity, input-use pattern, tillage practice, productivity in basmati and non-basmati variety, the variety-wise further analysis was done on DSR and non-DSR practising farms respectively. 


\section{Data Envelopment Analysis Approach (DEA)}

DEA calculates Technical Efficiency (TE) scores, which reflects the ability of farmers to obtain maximal output from a given set of inputs. There are a number of methodological approaches to the measurement of productivity and efficiency using cross-sectional data. This methodology can be divided into three groups: (1) traditional productivity and efficiency analysis based on ratios (2) stochastic frontier analysis using econometrics and (3) DEA using linear programming (LP). Ratio based analysis, such as output per unit cropped area (Total production value /irrigated area (ha) and output per unit irrigation supply (Total production value/ irrigation supply $\left(\mathrm{m}^{3}\right)$, is relatively easier to calculate and understand. However, such measures do not take into account differences in non-water inputs (labour, capital, etc.) between organization (Coelli et al. 1998; Speelman et al. 2008). Compared to stochastic frontier analysis, the advantage of DEA include the following : (1) the method does not require a specific production function or parametric assumptions, (2) the method permits a study to be performed with several outputs (Diaz et al. 2004a,b), (3) the decision maker does not need prior information about the weights of inputs and outputs, (4) for each organization, efficiency is compared to that of an ideal (optimum) operating organization, rather than to the calculate average performance (Raju and Kumar, 2006; Phandis and Kulshrestha 2010) and (5) DEA also allows for the identification of improvements in inputs and outputs that are required to make a unit efficient (Talluri 2000). DEA is one of several techniques that can be used to calculate a best practice production frontier (Coelli et al. 1998; Kumbhakar and Lovel 2000). The Farrell measure equals one for the efficient farmer on the frontier, and then decrease with inefficiency.

Although benchmarking in DEA allows for the identification of targets for improvements, it has certain limitations. DEA does not account for random data error, which can be significant in agriculture (Diaz et al. 2004a). But still DEA is a useful tool for identifying inefficient use of inputs and changes that may be applied to such decision making units that can be farmers or organizations etc. to increase their efficiency (Yilmaz et al. 2009).
The Technical Efficiency (TE) can be expressed generally as the ratio of sum of the weighted outputs to sum of weighted inputs. The value of technical efficiency varies between zero and one; where a value of one implies that the DMU is the best performer located on the production frontier and has no reduction potential. Any value of TE lower than one indicates that the DMU uses inputs inefficiently (Mousavi-Avval et al. 2011).

Pure Technical Efficiency is another model in DEA that was introduced by Banker et al. 1984. Pure Technical efficiency could separate both technical and scale efficiencies. The main advantage of this model is that the scale inefficient farms are only compared to efficient farms of a similar size (Bames, 2006).

Scale Efficiency shows the effect of DMU size on efficiency of system. Simply, it indicates that some part of inefficiency refers to inappropriate size of DMU, and if DMU moved toward the best size, the overall efficiency (technical) could be improved at the same level of technologies (inputs) (Nassiri and Singh, 2009). If a DMU is fully efficient in both the technical and pure technical efficiency scores, it is operating at the most productive scale size. If a DMU has the full pure technical efficiency score, but a low technical efficiency score, then it is locally efficient but not globally efficient due to its scale size. Thus, it is reasonable to characterize the scale efficiency of a DMU by the ratio of the two scores (Sarica and Or, 2007). The relation among the scale efficiency, technical efficiency and pure technical efficiency can be expressed as (Chauhan et al. 2006):

$$
\text { Scale Efficiency }=\frac{\text { Technical Efficiency }}{\text { Pure Technical Efficiency }}
$$

In this study TE under VRS was estimated and results were presented by using Data Envelopment Analysis Program (DEAP) version 2.1.

The production of paddy crop (both varietiesbasmati as well non-basmati) per hectare (in quintals) was taken as the output (Y). The different inputs considered for the analysis were as follows:

$\mathrm{X}_{1}=$ Water use $\left(\mathrm{m}^{3} \mathrm{ha}^{-1}\right)$

$\mathrm{X}_{2}=$ Total Fertilizers $\left(\mathrm{Kg} \mathrm{ha}^{-1}\right)$

$\mathrm{X}_{3}=$ Plant protection $\left(₹ \mathrm{ha}^{-1}\right)$

$\mathrm{X}_{4}=$ Seed/Seedling $\left(₹ \mathrm{ha}^{-1}\right)$ 
$\mathrm{X}_{5}=$ Total Hired labour (hour ha-1)

$\mathrm{X}_{6}=$ Tractor use (hour ha-1)

\section{RESULTS AND DISCUSSION}

The perusal of Fig. 1 reveals that over time rate of over-exploitation has increased. In 1984 the proportion of Over- Exploited (OE) blocks was 45 per cent which swelled to 78.98 per cent in 2011. The white blocks which were 30.5 per cent in 1984 decreased to only about 15.94 per cent in 2011. As a matter of fact, the white blocks are only those blocks where extraction is either technically not feasible due to brackish water in south-west zone or is economically unviable due to rocky terrain in kandi zone This scenario of over-exploitation brings forth the fact that limited quantity of surface water resources and an over-time decline in their quantity as compared with increased demand for water on account of increasing cropping intensity, water intensive rice-wheat rotation, increased urbanization and industrialization have put huge pressure on ground water resources (Kaur et al. 2015).

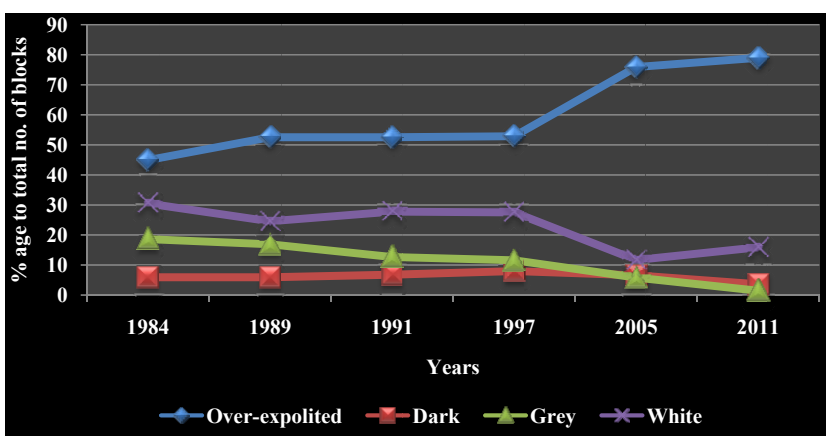

Fig. 1: Increase in over-expolited and dark blocks in Punjab, 1984 to 2011

The status of ground water resources depends on the net annual recharge from replenishing sources and the net annual draft for different purposes. The block wise net annual recharge and draft figures obtained from various studies done by Water Recourses Directorate, Punjab, Chandigarh were summed up into different districts of the state as per the blocks falling in the year 2011, for making comparisons, thus the number of districts falling in study years 1984, 89, 91, 97 and 2005 were changed into 20 districts as per the study year 2011. The districts were clubbed to find out the zone wise ground water recharge and balance estimates (Fig. 2 ). The ground water balance of Punjab state was $0.02 \mathrm{~m}$ ha $\mathrm{m}$ in 1997 which decreased to $-0.89 \mathrm{~m}$ ha m, over a span of 7 years (1997-2005), a decline by 44 times than the preceding year. This figure reached to $-1.38 \mathrm{~m}$ ha $\mathrm{m}$ in the year 2011 showing decline by 1.5 times than the preceding year. Recently fall in the rate of decline has occurred due to in enactment of "Sub Soil Water Preservation Act" of 2008 which prohibits the transplantation of paddy in the field before $10^{\text {th }}$ June. The water balance estimates of Central Zone are not only negative but also showed an increasing trend over time (Kaur et al. 2015).

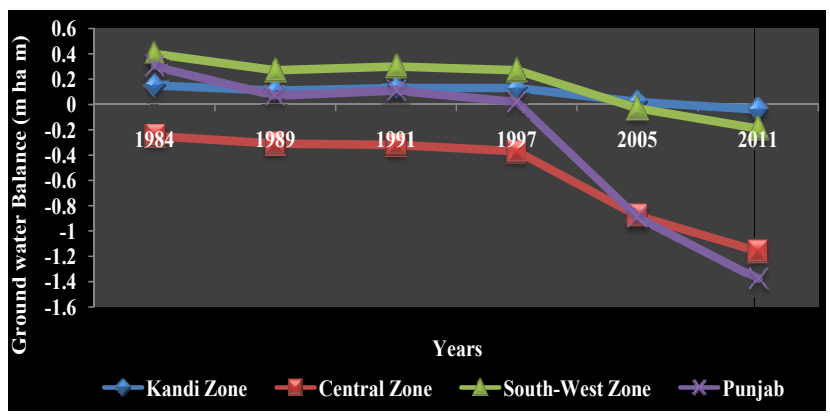

Fig. 2: Zone-wise comparison of ground water development in Punjab, 1984 to 2011

Due to receding water table (Humphreys et al. 2005), rising costs of labour for transplanting of paddy (Singh et al. 2005) and the adverse effects of puddling on soil health (Timsina and Connor, 2001); direct seeded rice (DSR) is gaining popularity. The present study compares the resource-use pattern and resource-use efficiency of direct seeding of rice in comparison to that of the transplanted method by collecting primary data from villages i.e. Chandbaza from Fardikot block, Sibian and Ukand wala from Kotkapura, Gill and Ghall khurd from Ghall khurd block and Sadhon ke chak from Gurhar-shai block.

\section{Socio-economic characteristics of sample farmers}

The socio-economic characteristics such as age, education, years of farming experience, family size, etc. are considered to be the important determinants of adoption of any technology or practice. The socio-economic characteristics of the adopters of DSR technology and the non-adopters have been presented in Table 1. Among the adopters of DSR technology, about 67.50 percent of the respondents i.e. more than half of them were below 40 years of age which clearly revealed that technology adopters were mostly young and were keen to go for new techniques of crop production. 
Table 1: Socio-economic Characteristic of sample farmers, Punjab, 2012-13 (Numbers)

\begin{tabular}{|c|c|c|c|}
\hline Particulars & $\begin{array}{c}\text { DSR } \\
\text { Respondents }\end{array}$ & $\begin{array}{c}\text { Non-DSR } \\
\text { Respondents }\end{array}$ & $\begin{array}{c}\text { Overall } \\
\text { Respondents }\end{array}$ \\
\hline \multicolumn{4}{|l|}{ Age (years) } \\
\hline Up to 30 & $3(7.5)$ & $2(5)$ & $5(6.25)$ \\
\hline $30-40$ & $24(60)$ & $13(32.5)$ & $37(46.25)$ \\
\hline $41-50$ & $9(22.5)$ & $9(22.5)$ & $18(22.5)$ \\
\hline Above 50 & $4(10)$ & $16(40)$ & $20(25)$ \\
\hline \multicolumn{4}{|c|}{ Education Standard } \\
\hline Illiterate & $5(12.5)$ & $5(12.5)$ & $10(12.5)$ \\
\hline $\begin{array}{l}\text { Up to } \\
\text { primary }\end{array}$ & 15(37.5) & $17(42.5)$ & $32(40)$ \\
\hline Matric & $11(27.5)$ & $6(15)$ & $17(21.25)$ \\
\hline Secondary & $8(20)$ & $8(20)$ & $16(20)$ \\
\hline $\begin{array}{l}\text { Post- } \\
\text { Graduate }\end{array}$ & $1(2.5)$ & $4(10)$ & $5(6.25)$ \\
\hline \multicolumn{4}{|c|}{ Experience (years) } \\
\hline Upto 10 & $5(12.5)$ & $5(12.5)$ & $10(12.5)$ \\
\hline $10-15$ & $3(7.5)$ & $8(20)$ & 11(13.75) \\
\hline $15-20$ & $11(27.5)$ & $3(7.5)$ & $14(17.5)$ \\
\hline 20 \& above & $21(52.5)$ & $24(60)$ & $45(56.25)$ \\
\hline
\end{tabular}

Figure in parentheses are percentages to total no. of farmers.
Education generally enables a man to think and judge a situation in a rational way. The study revealed that 77.50 per cent of the technology adopters had cleared $X^{\text {th }}$ whereas most of the nonadopters were educated upto primary level. The farmers practising non-conventional method of paddy transplanting having more than 20 years of agricultural experience were 60 per cent where as 47.50 per cent of the sample farmers who adopted this technology had agricultural experience of less than 20 years, which clearly revealed that technology adopters were mainly young farmers.

\section{Input-use pattern, costs and returns of DSR farms vs. Non-DSR farms}

The persual of the Table 2 gives an overview of the input and output variables used in the DEA model. The average water-use of basmati in nonDSR fields was 6452.33 cubic metre per hectare $\left(\mathrm{m}^{3}\right.$ ha $^{-1}$ ); whereas it was $4639.04 \mathrm{~m}^{3} \mathrm{ha}^{-1}$ in DSR fields; depicting a water saving of 28.10 per cent on DSR farms. DSR was effective in saving of irrigation water to the tune of 28.10 per cent in basmati fields and 25.33 per cent in non basmati fields. It is due to

Table 2: Descriptive Statistics Regarding Inputs and Output of DEA model

\begin{tabular}{|c|c|c|c|c|c|c|}
\hline \multirow[t]{2}{*}{ Particulars } & \multicolumn{3}{|c|}{ DSR } & \multicolumn{3}{|c|}{ Non-DSR } \\
\hline & Lowest & Highest & Average & Lowest & Highest & Average \\
\hline \multicolumn{7}{|l|}{ Basmati } \\
\hline Yield (Kg/ ha) & 40 & 44.50 & 42.32 & 33.34 & 45.44 & 39.09 \\
\hline Seed (₹/ha) & 444.60 & 1185.60 & 720.33 & 1160.90 & 1358.50 & 1289.89 \\
\hline Fertilizers (Kg/ha) & 456.95 & 679.25 & 481.91 & 481.51 & 654.91 & 529.44 \\
\hline Water Use ( $\left.\mathrm{M}^{3} / \mathrm{ha}\right)$ & 3572.56 & 5690.23 & 4639.04 & 5720.52 & 7149.17 & 6452.33 \\
\hline Plant Protection (₹/ha) & 2828.15 & 5582.20 & 3690.41 & 1716.65 & 2519.40 & 2375.09 \\
\hline Tractor Use (Hrs/ha) & 4.20 & 15.80 & 9.54 & 4.43 & 19.76 & 12.12 \\
\hline Total Variable Cost (₹/ha) & 13568.0 & 17785.90 & 15755.0 & 16879.03 & 22568.19 & 19380.82 \\
\hline Gross Returns (₹/ha) & 95003.3 & 125609.0 & 115566 & 88179 & 119548 & 105765.85 \\
\hline Net Returns (₹/ha) & 81435.30 & 107823.10 & 99811 & 71299.97 & 96979.80 & 86385.03 \\
\hline \multicolumn{7}{|l|}{ Non-Basmati } \\
\hline Yield (Kg/ha) & 64.22 & 76.57 & 69.90 & 62 & 74.10 & 70.15 \\
\hline Seed (₹/ha) & 370.50 & 1185.60 & 690.43 & 1111.50 & 1358.50 & 1262.76 \\
\hline Fertilizers (Kg/ha) & 407.45 & 575.20 & 455.66 & 481.50 & 654.91 & 533.85 \\
\hline Water Use $\left(\mathrm{M}^{3} / \mathrm{ha}\right)$ & 3966 & 6811.69 & 5549.72 & 5187 & 9910 & 7432.51 \\
\hline Plant Protection (₹/ha) & 2470 & 6805.20 & 3657.81 & 1716.65 & 3709.94 & 2351.03 \\
\hline Tractor Use (Hrs/ha) & 5.26 & 25.12 & 9.71 & 3.39 & 30.00 & 9.15 \\
\hline Total Variable Cost (₹/ha) & 14523.65 & 18597.56 & 16468.38 & 18547.59 & 24569.87 & 21240.31 \\
\hline Gross Returns (₹/ha) & 86379 & 95874.23 & 89472.00 & 85363.20 & 94848 & 89792 \\
\hline Net Returns (₹/ha) & 71855.35 & 77277 & 73003.62 & 66815.61 & 70278.31 & 68551.69 \\
\hline
\end{tabular}


the fact that in direct rice, the irrigation is applied at 3 and 4 days interval instead of continuous ponding during early establishment. Further, when the crop becomes one month old, the irrigation is applied at 7 to 9 days interval, thereby increasing the irrigation efficiency of crop. This clearly implied that the adopters of DSR technology were more water efficient than non-adopters of the technology.

Though, the average use of other inputs (tractor use, fertilizer, etc.) in basmati as well as non-basmati varieties was high for non-adopters than adopters of DSR technology except for the plant protection, in which the expenditure spent was more in the case of DSR technology (₹ 3690.41 per ha) as compared to non-DSR technology (₹ 2375.09 per ha).

The variable cost per hectare was less on DSR farms (₹ 15755) as compared to non-DSR farms (₹ 19380.32) thereby resulting into a cost saving of 18.70 per cent. The use direct seeding rice technology resulted into decreases in expenditure of rice cultivation ranging from ₹ 3900 to ₹ 5000 per hectare across varieties mainly due to labour saving. This clearly implied that the adopters of DSR technology were more water efficient than non-adopters of the technology. Hence, on DSR farms the profit was amplified by 15.54 per cent in basmati and 6.52 per cent in nonbasmati varieties respectively.

\section{Regions of operation in the production frontier}

In addition to knowing about the number of efficient farms, extent of inefficiency and optimum scale of operation, it is also important to understand the distribution of farms in the three regions of production frontier, i.e. how many farms are under increasing, decreasing or constant returns.

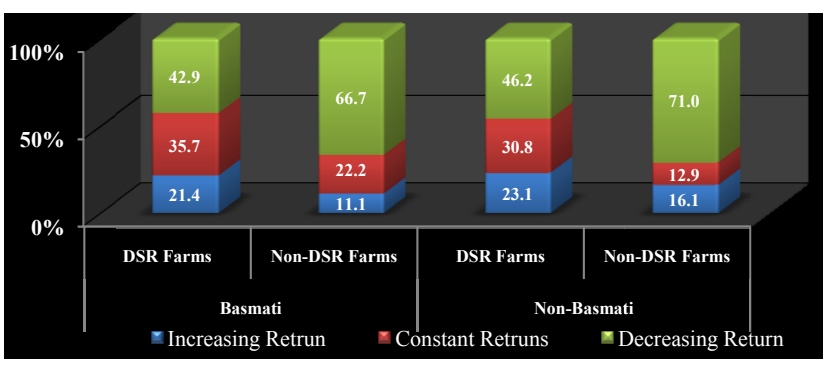

Fig. 3: Distribution of sample farms according to their type of returns

In case of DSR farms 21.43 percent of basmati growers and 23.07 per cent of non-basmati growers were found operating in the region of increasing returns or the sub-optimal region, whereas, only 11.11 per cent and 16.12 per cent of the non-DSR ones were found in respected region in basmati and non-basmati varieties respectively (Fig. 3). The production scale of these farms could be increased by decreasing the costs, since they were performing below the optimum production scale. In the constant region of frontier, i.e. optimum scale of production, about 30.77 to 35.71 per cent of DSR farms were found in this scale, whereas, 12.91 to 22.22 per cent of non-DSR farms were operating in the region of constant returns to scale. Further a large proportion i.e. about 70 per cent of non-DSR farms were found in decreasing returns region as compared to just 42 per cent DSR ones i.e. the non-DSR farms could increase their technical efficiency by reducing their input-use. This region is also called as superoptimal, i.e. the farms were performing above the optimum scale of production.

Distribution of farmers according to the level of overall technical efficiency in the paddy cultivation

A large proportion of the farmers who adopted the technology were in between the efficiency level of 80-100 per cent, whereas the non-adopters were less than 70 per cent efficient (Table 3). This was true for both the varieties Pusa Basmati 1121 (Basmati) and PR-114,118 (Non-basmati).

Table 3: Distribution of farmers according to the level of overall technical efficiency in the paddy cultivation, Punjab, 2012-13

\begin{tabular}{ccccc}
\hline \multirow{2}{*}{$\begin{array}{c}\text { Levels of } \\
\text { technical } \\
\text { efficiency (\%) }\end{array}$} & $\begin{array}{c}\text { Basmati } \\
\text { DSR } \\
\text { farms }\end{array}$ & $\begin{array}{c}\text { Non- } \\
\text { DSR } \\
\text { farms }\end{array}$ & $\begin{array}{c}\text { DSR } \\
\text { farms }\end{array}$ & $\begin{array}{c}\text { Non-DSR } \\
\text { Farms }\end{array}$ \\
\hline $60-70$ & $0(0)$ & $4(44.45)$ & $2(7.69)$ & $15(48.38)$ \\
$70-80$ & $2(14.28)$ & $2(22.22)$ & $2(7.69)$ & $8(25.80)$ \\
$80-90$ & $4(28.58)$ & $1(11.11)$ & $10(38.47)$ & $5(16.12)$ \\
$90-100$ & $8(57.14)$ & $2(22.22)$ & $12(46.15)$ & $3(9.67)$ \\
\hline Total & $\mathbf{1 4 ( 1 0 0 )}$ & $\mathbf{9 ( 1 0 0 )}$ & $\mathbf{2 6 ( 1 0 0 )}$ & $\mathbf{3 1 ( 1 0 0 )}$ \\
\hline
\end{tabular}

Note: Figures in parentheses indicate the per cent to the total number of farmers in each category.

The frequency distribution of technical efficient farmers w.r.t water-use in paddy cultivation was presented in Table 4 . The majority of the technical efficient farmers (78.57 per cent) who cultivated their farms by using direct seeding of rice method had the technical efficiency of equal to or more than 
60 per cent. While majority of the farmers (77.78 per cent) who used conventional method of cultivation on their farms had the technical efficiency less than 60 per cent in basmati variety. While in case of nonbasmati variety about 84 per cent of farmers who had not used DSR technology had the technical efficiency ranging between 50-70 per cent. Whereas, about 60 per cent of farmers who had adopted DSR technology had technical efficiency ranging between 70-100 per cent; thereby indicating that larger proportion of adopters were more than 70 per cent efficient whereas non-adopters were less than 60 per cent efficient.

Table 4: Distribution of farmers according to the level of technical efficiency w.r.t water-use in paddy cultivation, Punjab, 2012-13

\begin{tabular}{|c|c|c|c|c|}
\hline \multirow{2}{*}{$\begin{array}{c}\text { Levels of } \\
\text { technical } \\
\text { efficiency (\%) }\end{array}$} & \multicolumn{2}{|c|}{ Basmati } & \multicolumn{2}{|c|}{ Non-basmati } \\
\hline & $\begin{array}{c}\text { DSR } \\
\text { farms }\end{array}$ & $\begin{array}{l}\text { Non- } \\
\text { DSR } \\
\text { farms }\end{array}$ & $\begin{array}{c}\text { DSR } \\
\text { farms }\end{array}$ & $\begin{array}{l}\text { Non-DSR } \\
\text { farms }\end{array}$ \\
\hline Upto 50 & $1(7.15)$ & $3(33.33)$ & $0(0)$ & $3(9.67)$ \\
\hline $50-60$ & $2(14.28)$ & $4(44.44)$ & $0(0)$ & $6(19.35)$ \\
\hline $60-70$ & $5(35.72)$ & $0(0)$ & $8(30.76)$ & $17(54.53)$ \\
\hline $70-80$ & $3(21.42)$ & $1(22.22)$ & $11(42.32)$ & $3(9.67)$ \\
\hline $80-90$ & $1(7.15)$ & $0(0)$ & 3 (11.54) & $1(3.22)$ \\
\hline $90-100$ & $2(14.28)$ & 1 (11.11) & $4(15.38)$ & $1(3.22)$ \\
\hline Total & $14(100)$ & $9(100)$ & $26(100)$ & $31(100)$ \\
\hline
\end{tabular}

Note: Figures in parentheses indicate the per cent to the total number of farmers in the category.

\section{Comparison of DSR vs. Non-DSR farms in relation to their efficiency levels and input-use pattern}

In order to present the comparison of DSR vs. nonDSR farms with regard to their efficiency levels and input-use pattern, per hectare use of different inputs was calculated for the sample farmers and were grouped into four groups representing different levels of efficiency. The efficiency level of all the farmers was calculated by using DEA model as already discussed. This regards between zero per cent and 100 per cent. These farmers were classified in four groups according to their efficiency levels discussed in Table 5.

Farmers that operate at 90 per cent or more have been considered as highly efficient farmers, whereas, those farmers with technical efficiency score ranging between 70 per cent to 90 per cent were considered as less efficient farmers. The highly efficient farmers which are categorized under group IV incurred expenditure of ₹ 544.60 per hectare on seed, used hired labour for 58.43 hours, their tractor-use per hectare was 8.20 hours (indicating least expenditure incurred on diesel oil), water-use on their fields for irrigating paddy crop for whole season was 3374.16 cubic meter, manures and fertilizers applied on their fields were $396.25 \mathrm{~kg}$ and expenditure on plant protection chemicals was ₹ 3019.57 per hectare respectively. The group I farmers with efficiency level less than 70 per cent incurred

Table 5: The comparison of DSR vs. Non-DSR farms in relation to their efficiency levels and input-use pattern in basmati variety of sample farms, Punjab, 2012-13 (Per hectare)

\begin{tabular}{|c|c|c|c|c|c|c|c|}
\hline $\begin{array}{c}\text { Efficiency } \\
\text { level }\end{array}$ & $\begin{array}{c}\text { Practice/ } \\
\text { Technology }\end{array}$ & $\begin{array}{c}\text { Seed/ } \\
\text { Seedlings } \\
\text { (₹/ha) }\end{array}$ & $\begin{array}{c}\text { Total hired } \\
\text { labour (hours/ } \\
\text { ha) }\end{array}$ & $\begin{array}{l}\text { Tractor-use } \\
\text { (hours/ha) }\end{array}$ & $\begin{array}{l}\text { Water-use } \\
\left(\mathrm{m}^{3} / \mathrm{ha}\right)\end{array}$ & $\begin{array}{c}\text { Total } \\
\text { fertilizers } \\
\text { (Kg/ha) }\end{array}$ & $\begin{array}{c}\text { Plant } \\
\text { protection } \\
\text { (₹/ha) }\end{array}$ \\
\hline \multirow{2}{*}{$\begin{array}{c}\text { Group I } \\
\text { Less than70 }\end{array}$} & DSR farms & $966.18(35.72)$ & $62.48(14.28)$ & $14.37(7.14)$ & 4814.67 (14.28) & $467.51(7.14)$ & 4807.51 (71.44) \\
\hline & $\begin{array}{l}\text { Non-DSR } \\
\text { farms }\end{array}$ & $1320.59(11.11)$ & $136.51(22.2)$ & $15.93(11.11)$ & $7255.05(44.44)$ & $535.03(33.33)$ & $2447.17(22.22)$ \\
\hline $\begin{array}{c}\text { Group II } \\
70-80\end{array}$ & DSR farms & $740.59(50.00)$ & $61.45(7.14)$ & $12.29(14.29)$ & $3987.71(21.43)$ & $439.16(14.28)$ & $4124.90(7.14)$ \\
\hline \multirow{2}{*}{$\begin{array}{c}\text { Group III } \\
80-90\end{array}$} & DSR farms & $587.86(7.14)$ & $60.45(7.14)$ & $9.76(14.29)$ & $3454.19(7.14)$ & $402.70(42.86)$ & $3692.15(7.14)$ \\
\hline & $\begin{array}{l}\text { Non-DSR } \\
\text { farms }\end{array}$ & 1197.95 (22.22) & $126.83(11.11)$ & $11.51(22.22)$ & $6544.23(33.33)$ & $462.80(22.22)$ & $1716.65(22.22)$ \\
\hline $\begin{array}{c}\text { Group IV } \\
90-100\end{array}$ & DSR farms & $544.60(7.14)$ & $58.43(71.44)$ & $8.20(64.28)$ & $3374.16(57.15)$ & $396.25(35.72)$ & $3019.57(14.28)$ \\
\hline
\end{tabular}




\begin{tabular}{|c|c|c|c|c|c|c|c|}
\hline \multicolumn{8}{|c|}{ Non-Basmati } \\
\hline $\begin{array}{c}\text { Efficiency } \\
\text { level }\end{array}$ & $\begin{array}{c}\text { Practice/ } \\
\text { Technology }\end{array}$ & $\begin{array}{c}\text { Seed/ } \\
\text { Seedlings } \\
(₹ / h a)\end{array}$ & $\begin{array}{c}\text { Total hired } \\
\text { labour (hours/ } \\
\text { ha) }\end{array}$ & $\begin{array}{l}\text { Tractor-use } \\
\text { (hours/ha) }\end{array}$ & $\begin{array}{c}\text { Water-use } \\
\left(\mathrm{m}^{3} / \mathrm{ha}\right)\end{array}$ & $\begin{array}{c}\text { Total } \\
\text { fertilizers } \\
\text { (Kg/ha) }\end{array}$ & $\begin{array}{c}\text { Plant } \\
\text { protection } \\
\text { (₹/ha) }\end{array}$ \\
\hline & DSR farms & 896.96 (26.92) & $40.74(7.69)$ & $13.32(11.54)$ & 5553.39 (15.39) & $482.77(9.68)$ & $4819.31(84.60)$ \\
\hline Les & $\begin{array}{c}\text { Non-DSR } \\
\text { farms }\end{array}$ & $1333.80(3.22)$ & $178.20(35.49)$ & $15.59(67.74)$ & 8183.45 77.41) & $580.20(32.26)$ & $2589.95(48.38)$ \\
\hline & DSR farms & $663.90(7.69)$ & $40.26(19.23)$ & $11.64(26.92)$ & $5792.15(23.08)$ & 462.39 (30.77) & $4119.31(7.70)$ \\
\hline 70-80 & $\begin{array}{l}\text { Non-DSR } \\
\text { farms }\end{array}$ & 1316.16 41.93) & $155.5(51.62)$ & $13.26(16.12)$ & 8081.59 (16.12) & $547.63(48.38)$ & 2066.57 (9.67) \\
\hline Group III & DSR farms & $545.46(11.54)$ & $35.67(7.69)$ & $9.50(3.85)$ & $5762.02(11.54)$ & $434.40(44.16)$ & $3540.51(3.85)$ \\
\hline 80-90 & $\begin{array}{l}\text { Non-DSR } \\
\text { farms }\end{array}$ & $1269.70(32.26)$ & $146.85(6.45)$ & $11.75(12.90)$ & $7883.51(3.23)$ & $514.96(9.68)$ & 2061.57 (19.35) \\
\hline Group IV & DSR farms & $501.38(53.85)$ & $28.63(65.39)$ & $8.26(57.69$ & 4764.44 (49.99) & 411.45 (15.39) & $2870.23(3.85)$ \\
\hline 90-100 & $\begin{array}{c}\text { Non-DSR } \\
\text { farms }\end{array}$ & $1245.10(22.59)$ & $138.89(6.45)$ & $10.50(3.23)$ & $7635.21(3.23)$ & $452.83(9.68)$ & 2056.29 (22.59) \\
\hline
\end{tabular}

Note: Figures in parentheses indicate the per cent to the total number of farmers in the category.

more expenditure on all inputs of paddy crop and even used more labour and fertilizers which should be decreased to reach optimum efficiency level. The less efficient farmers should follow the input-use pattern of highly efficient farmers to reach the production frontier. This is true for all sample farmers whether basmati growers or non-basmati growers. Thus, we can conclude that in non-basmati variety, group I farmers have to decrease their per hectare input-use i.e. decrease their expenditure on seed by ₹ 395.58, use of hired labour by 12.11 hours, use of tractor-use by 5.06 hours, use of irrigation water by 788.95 cubic meter, use of fertilizers by $71.32 \mathrm{~kg}$ and decrease in expenditure on plant protection by ₹ 1949.80 to reach optimal efficiency.

\section{CONCLUSION}

Socio-economic profile of the farmers clearly revealed that the adoption of this technology was made by young, educated and progressive farmers. A significant saving of 18 per cent was achieved for irrigating one hectare of the DSR farm in basmati and non-basmati varieties as compared to nonDSR farm. The mean overall technical efficiency was more in DSR farms as compared with nonDSR farms, with difference of about 12 per cent in basmati and 5 per cent in non-basmati fields. However, this difference was 7 per cent in basmati and 14 per cent in non basmati while calculating the average technical efficiency w.r.t. water-use. About 70 per cent of non-DSR farms were found in decreasing returns regions as compared to just 42 per cent DSR ones i.e. the non-DSR farms could increase their technical efficiency by reducing their input use that means the direct seeding of rice technology improved the irrigation efficiency of paddy crop. The important constraints in the adoption of this technology include non-availability of seed drill, high amount of unwanted plants and lack of awareness. To encourage the rapid adoption of the technology, there is need to ensure timely availability of seed drill preferably in Agro Machinery Service Centro (AMSC) of the state, extensive research and development of weed resistant varieties and capacity buildings of farmers for effective management of weed and pest in direct seeded rice. Strengthening of AMSC's and increased extension efforts for capacity buildings of farmers will go a long way for increasing the area under this technology as more farmers will go for its adoption.

\section{REFERENCES}

Ali, M. and Byerlee, D. 2000. Productivity growth and resource degradation in Pakistan's Punjab: A decomposition analysis. Policy Research Working Paper No. 2480. Washington, DC: World Bank.

Awan, I.U., Alizai, H.U. and Chaudhry, F.M. 1989. Comparative study of direct seeding and transplanting methods on the grains yield of rice, Sarhad J. Agric., 5: 119-24.

Bames, A. 2006. Does multi-functionality affect technical efficiency. A non-parametric analysis of the Scottish dairy industry. J of Environmental Management, 80(4): 287-94.

Byerlee, D. and Siddiq, A. 1994. Has the Green Revolution been sustained? The quantitative impact of the seed-fertilizer revolution in Pakistan revisited. World Development, 22: 1345-61.

Chauhan, N.S., Mohapatra, P.K.J. and Pandey, K.P. 2006. Improving energy productivity in paddy production 
through benchmarking-an application of data envelopment analysis. Energy Conversion Management, 47(9-10): 1063-1085.

Coelli, TA. 1998. Guide to DEAP version 2-1: A Data Envelopment Analysis (computer) Program, Working Paper 96/08, 1998; CEPA, UNE, Australia.

Diaz, J., Poyato, E.C. and Luque, R.L. 2004. Application of data envelopment analysis to studies of irrigation efficiency. In Andalusia. Journal of Irrigation and Drainage Engineering, 130(3): 175-83.

Duxbury, J.M., Abrol, I.P., Gupta, R.K. and Bronson, K.F. 2000. Analysis of long-term fertility experiments with ricewheat rotations in South Asia. In I.P. Abrol, K.F. Bronson, J.M. Duxbury, and R.K.Gupta (eds.), Long-term soil fertility experiments in rice-wheat cropping systems. 2000; Rice Wheat Consortium Paper Series 6. New Delhi, India: RWC. Pp. vii-xxii.

Government of Punjab. 2011. Block-wise abstract of ground water estimate, Water Resources Directorate, Chandigarh, Punjab.

Gupta, R.K., Naresh, R.K., Hoobs, P.R., Jiaguo, Z. and Ladha, J.K. 2003. Sustainability of post-green revolution agriculture: The rice-wheat cropping systems of the IndoGangetic Plains and China. In J.K. Ladha, J.E. Hill, J.M. Duxbury, R.K Gupta, and R.J. Buresh (eds.), Improving the productivity and sustainability of rice-wheat systems: Issues and impacts. ASA Special Publication Number 65. Madison, Wisconsin, USA: ASA-CSSA-SSSA, pp. 1-26.

Humphreys, E., Meisner, C., Gupta, R.K., Timsina, J., Beecher, H.G., Tang, Y.L., Singh, Y., Gill, M.A., Masih, I., Zeng, J.G. and Thompson, J.A. 2005. Water saving in rice-wheat system. Plant Prod Sci., 8: 242-58.

Kaur, B., Vatta, K. and Sidhu, R.S. 2015. Optimising irrigation water use in Punjab agriculture; role of crop diversification and technology. Ind. J. Agri. Econ., 70(3): 307-12.

Kumar, A. and Yadav, D.S. 2002. Long term effects of fertilizers on the soil fertility and productivity of a rice wheat system. Journal of Agronomy and Crop Science, 186: 47-54.

Kumar, P., Jha, D., Kumar, A., Chaudhary, M.K., Grover, R.K., Singh, R.K., Mitra, A., Joshi, P.K., Singh, A., Badal, P.S., Mittal, S. and Ali, J. 2002. Economic analysis of total factor productivity of crop sector in Indo-Gangetic Plain of India by district and region. Agricultural Economics Research Report 2. 2002; New Delhi, India: Indian Agricultural Research Institute.

Kumbhakar, S.C. and Knox Lovel, C.A. 2000. Stochastic Frontier Analysis. 2000; UK: Cambridge University Press.

Ladha, J.K., Dawe, D., Pathak, H., Padre, A.T., Yadav, R.L., Singh, B., Singh, Y., Singh, Y., Singh, P., Kundu, A.L., Sakal, R., Ram, N., Regmi, A.P., Gami, S.K., Bhandari, A.L., Amin, R., Yadav, C.R., Bhattarai, E.M., Das, S., Aggarwal, H.P., Gupta, R.K. and Hobbs, P.R. 2003. How extensive are yield declines in long term rice-wheat experiments in Asia? Field Crops Research, 81: 159-180.
Mitchell, J., Fukai, S. and Basanayake, J. 2004. Grain yield of direct seeded and transplanted rice in rainfed lowlands of south-East Asia. In: New Directions for a Diverse Palnet, Fisher R A (ed.), Sept. 26-Oct. 1, Proc $4^{\text {th }}$ International Crop Science Congress, 2004; Brisbane Australia.

Mousavi-Avval, S.H., Rafiee, S. and Mohammadi, A. 2011. Optimization of energy consumption and input costs for apple production in Iran using data envelopment analysis. Energy, 36: 909-16.

Nassiri, S.M. and Singh, S. 2009. Study on energy use efficiency for paddy crop using data envelopment analysis (DEA) technique. Applied Energy, 86(7): 1320-25.

Pandey, S. and Velasco, L. 2002. Economics of direct seeding rice in Asia: Patterns of adoption and research priorities. In: Pandey S, Mortimer, Wade L, Tuong T P, Lopez K and Hardy B (ed.) Direct Seeding: Research Strategies and opportunities. Proceedings of International workshop on direct seeding in Asian rice system, Jan 25-28, 2000 held at Bangkok, Thailand, IRRI, Los Banos, Phillipines, pp. 3-14

Patil, S.G., Sivaprasad, B., Aladakatti, Y.R., Siddalinga, D., Gupta, R. and Ladha, J.K. 2005. Agronomic practices and Production Economics of Direct-Seeded Rice in Karnatka, India. Rice-Wheat Consortium for the Indo-Gangetic Plains, Paper series 18, p 36, New Delhi, India.

Phadnis, S. and Kulshrestha, M 2010. Evaluation of irrigation inefficiency in Samrat Ashok Sagar major irrigation project by use of data envelopment analysis. International Journal of Civil and Structural Engineering, 1(2): 171-90.

Raju, K.S. and Kumar, D.N. 2006. Ranking irrigation planning alternatives using data envelopment analysis. Water Resources Management, 20: 553-56.

Sarica, K. and Or, I. 2007. Efficiency assessment of Turkish power plants using data envelopment analysis. Energy, 32(8): 1484-99.

Sidhu, R.S., Vatta, K. and Dhaliwal, H.S. 2010. Conservation agriculture in Punjab- Economic implications of technologies and practices. Ind. J. Agri. Econ., 65(3): 413-27.

Singh, K., Jat, A.S. and Sharma, S.K. 2005. Improving productivity and profitability of rice (Oryza sativa)-Wheat (Triticum aestivum) cropping system through tillage and planting management. Ind. J. Agric. Sci., 75(7): 396-99.

Srivastava, S.K., Chand Ramesh, Raju, S.S., Jain Rajni, I Kingsly, Sachdeva, J Singh Jaspal and Kaur Amrit. 2015. Unsustainable groundwater use in Punjab agriculture; Insight from cost of cultivation survey. Ind. J. Agri. Econ., 70(3): 365-78.

Tabbal, D.F., Bouman, B.A.M., Bhuiyan, S.I., Sibayan, E.B. and Sattar, M.A. 2002. On farm strategies for reducing water input in irrigated rice: case studies in Philippines. Agric. Water Mange., 56: 93-112.

Timsina, J. and Connor, D.J. 2001. Productivity and management of rice-wheat cropping systems: Issues and challenges. Field Crops Res., 69: 93-132. 
